\title{
Vulnerability Assessment of Building Frames Subjected to Progressive Collapse Caused by Earthquake
}

\author{
Fadzli Mohamed Nazri ${ }^{1, *}$, Mohamad Khairi Adha Zolkifle ${ }^{1}$, Hazrina Mansor ${ }^{2}$, and \\ Shahiron Shahidan ${ }^{3}$ \\ ${ }^{1}$ School of Civil Engineering, Engineering Campus, Universiti Sains Malaysia, 14300 Nibong Tebal, \\ Penang, Malaysia \\ ${ }^{2}$ Faculty of Civil Engineering, UiTM Shah Alam, 40450 Selangor, Malaysia \\ ${ }^{3}$ Jamilus Research Center, Faculty of Civil and Environmental Engineering, Universiti Tun Hussein \\ Onn Malaysia, 86400 Parit Raja, Johor, Malaysia
}

\begin{abstract}
Progressive collapse is an initial local failure of the structural component and leading to the additional collapse of the building frames. This study investigated the vulnerability of four- and six-storey moment resisting concrete frame (MRCF) buildings subjected to progressive collapse. The four- and six-storey MRCF buildings were designed based on British Standard (BS) and Eurocode (EC). The differences between these two codes were investigated. Nonlinear static analysis, which is also known as pushover analysis (POA), and nonlinear dynamic analysis or incremental dynamic analysis (IDA), were performed for each model to obtain capacity curve and explore vulnerability measures. IDA was conducted using a sample of ground motion from an earthquake that occurred in Ranau, Sabah in 2015. The four-storey building was more vulnerable than the six-storey building.
\end{abstract}

\section{Introduction}

Progressive collapse is described as building collapse caused by the loss or failure of a structural load-bearing member because of load hazards. Localized failure facilitates load redistribution to the adjacent member, which then initiates partial or total progressive collapse of a building. Mohamed [1] summarized several events that initiate progressive collapse, namely, gas explosion, blast, foundation failure, accidental impact, fire, and seismic force. According to Tavakoli [2], man-made or natural hazards can induce progressive collapse. Earthquakes may also cause progressive collapse caused by partial or complete failure of critical elements.

According to Byfield [3], the UK Building Regulations [4-5] was established after the incident in Ronan Point apartment in 1968. These regulations ensure a minimum level of structural integrity and modify the American and Canadian codes of practice [6-7]. The

* Corresponding author: cefmn@usm.my 
progressive collapse guidelines of the US General Administration [8] and US Department of Defense [9] were introduced after the Oklahoma City bombing and Twin Tower attack in the year of 1995 and 2001. Sasani [10] used SAP2000 to evaluate the three-dimensional model with Bernoulli beam elements; plastic hinges were localized, which are used to model material nonlinearity in beams, columns, and slabs. The approach employs a moment plastic hinge that only accounts for flexural plastic deformation; the plastic hinge is used to model localized plastic hinges. The hinge does not affect the response and structure of the element before yielding.

The progressive collapse of building structures is a complicated mechanical behavior of structural systems with large deformation. However, the lack of experimental technique and numerical simulation for structural systems limits research on this area. This study focuses on parameters that potentially affect progressive collapse, namely, plastic hinges and drifts. Plastic hinges are formed through bending and shear cracking. Building drift is caused by ground motion, such as earthquake. Such a motion could also lead to the deformation and failure of structural member. This study mainly aims (i) to identify the damage measures of building frames that affect the potential of progressive collapse and (ii) to compare the vulnerability of frame designs of buildings based on the British Standard (BS) and Eurocode (EC).

\section{Methodology}

Pushover analysis (POA) and incremental dynamic analysis (IDA) were conducted to identify the vulnerability of buildings. SAP 2000 software was used as a main tool in order to perform both static an dynamic analyses. The ground motion records from the Ranau earthquake was selected as the main data for the dynamic analysis. Two 3D building frame models of four- and six-storey buildings were analyzed. Two locations of column removal were adopted based on the guideline of the US General Service Administration (GSA) [8]. This analysis involved the following steps. One of the columns at the specific location (Fig. 1) were removed after the structure was designed in a 3D model. Cases 1 and 2 were then subjected to nonlinear analysis. Two cases of column removal were considered in accordance with Section 3.2.9 in the GSA guidelines [8]. Case 1 involves the removal of ground floor internal column at the middle of the building. Case 2 corresponds to the locations of the column removed from the ground floor of the internal middle and external middle sites as shown below.

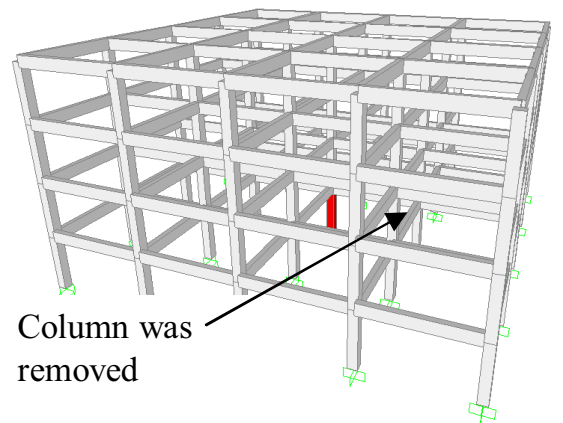

(a) Case 1: Internal Column Removed

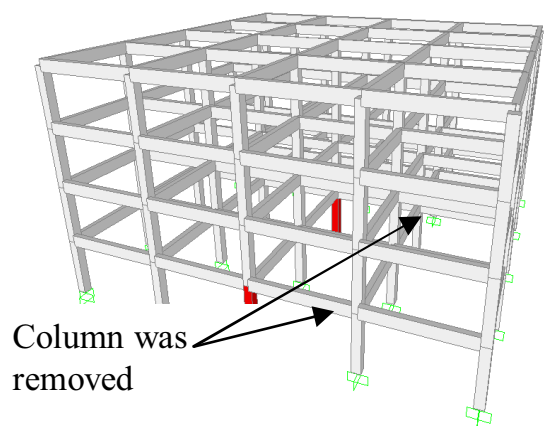

(b) Case 2: Simultaneously Removed Column

Fig. 1. Column Removal 


\section{Result and discussions}

POA was conducted by applying two load cases to the structure, namely, gravity loads and lateral loads. Gravity load included dead load (DL) and live load (LL), which were applied on the beams. Lateral loads were applied to the height of the building at each joint in a triangular distribution pattern. Four moment-resisting concrete frame (MRCF) models composed of two different storey heights were analyzed. The differences between the two design codes were compared based on force demand.

Fig. 2 (a) shows the maximum base shear of the four-storey BS-based design at approximately $4600 \mathrm{kN}$ and $1.5 \%$ drift. The maximum base shear of the six-storey BS was approximately $4100 \mathrm{kN}$ at $1.2 \%$ drift. The four-storey MRCF exhibited a higher base force demand than that of the six-storey MRCF. The maximum base force of the four-storey building in the EC-based design was $4300 \mathrm{kN}$ at $1.5 \%$ drift, which was higher than the maximum base force of $3900 \mathrm{kN}$ of the six-storey building at $1.2 \%$ drift.

BS-based design structure showed a higher base force demand than EC-based design. A four-storey model displayed the strong potential for progressive collapse of both design codes because the base force of the four-storey building is higher than that of the six-storey building. The columns in Case 2 [Fig. 2 (b)] were simultaneously removed. Case 2 shows that the four-storey building with BS-based design exerted a maximum base force of approximately $4200 \mathrm{kN}$ at $1.5 \%$ drift. The maximum base force of the six-storey BS was about $3700 \mathrm{kN}$ at $1 \%$ drift. By contrast, a slight decrease in base force was observed in the four-storey building designed using EC similar to that in Case 1. The maximum base force of the four-storey building designed using EC was about $3900 \mathrm{kN}$ at $1.5 \%$ drift. The maximum base force of the six-storey building designed using EC was $3500 \mathrm{kN}$ at $1 \%$ drift.

The comparison of column removal showed that Case 2, which involved simultaneous removal of columns, had a maximum base force lower than that of Case 1, wherein only one internal column was removed. Given the presence of column failure, the load supported by the failed column was transferred to the adjacent member that induced progressive collapse. The role of the structural member of the four-storey building in absorbing load redistribution was lower than that of the six-storey building. Thus, increase in base force rendered the low-rise building susceptible to progressive collapse. According to Tavakoli and Alashti [2], the role of additional elements in resisting progressive collapse increased as the number of storeys increased. This observation was explained by the fact that the weight of structural elements derived from column removal was transferred to other elements. Hoseini [11] also suggested that weight transfer increases pressure to the structure.

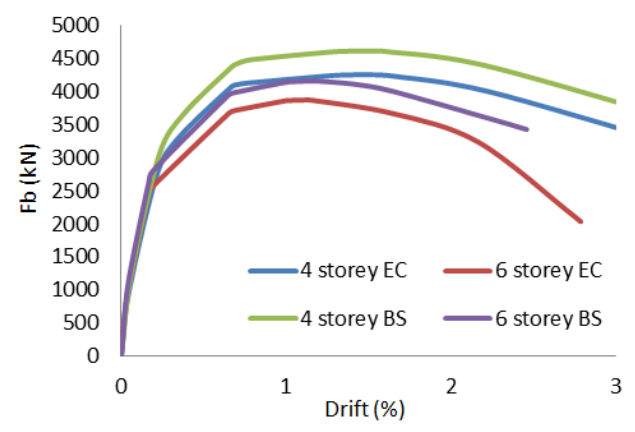

(a) Case 1: Internal column removal

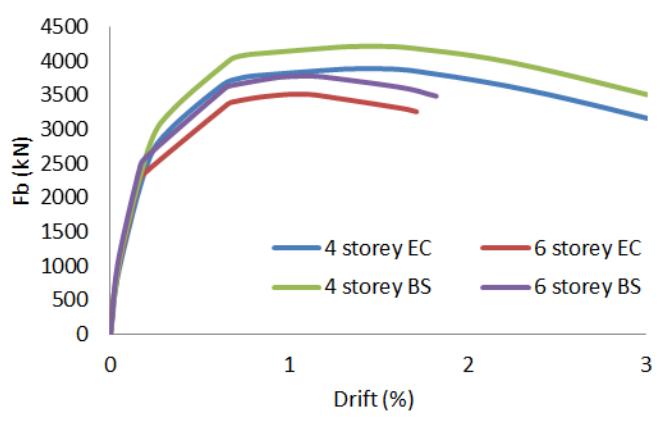

(b) Case 2: Simultaneous column removal

Fig. 2. POA result 
IDA was conducted for the four-storey model with Case 2 column removal, which was the worst case according to the POA. Fig. 3 shows the result of IDA analysis of the fourstorey building frame subjected to seismic loading. The sample was derived from the ground motion recorded in Kota Kinabalu from the earthquake in Ranau, Sabah. The graph shows that EC-based design recorded a PGA of $7.0 \mathrm{~m} / \mathrm{s}^{2}$ at $3 \%$ drift. Compared with the PGA of $6.0 \mathrm{~m} / \mathrm{s}^{2}$ under the BS-based design, only $1.0 \mathrm{~m} / \mathrm{s}^{2}$ was achieved under the ECbased design at 3\% drift. The plot for the EC-based design demonstrated a straight upward trend that reached to $10 \mathrm{~m} / \mathrm{s}^{2}$ PGA at about $4.2 \%$ drift. PGA for the BS-based design was $7.0 \mathrm{~m} / \mathrm{s}^{2}$ at $4 \%$ drift. PGA higher than that of the BS-based design must be attained to displace the building constructed under EC-based design. This requirement may be attributed to the notion that the design procedure considers seismic loading that acts on the building designed based on EC. The difference between the two design codes was about 1.0 $\mathrm{m} / \mathrm{s}^{2}$ PGA. BS-based design showed low performance under seismic loading because of lack of recommended guidelines for seismic design. The stiffness of the structural member was low because of the large displacement under low PGA.

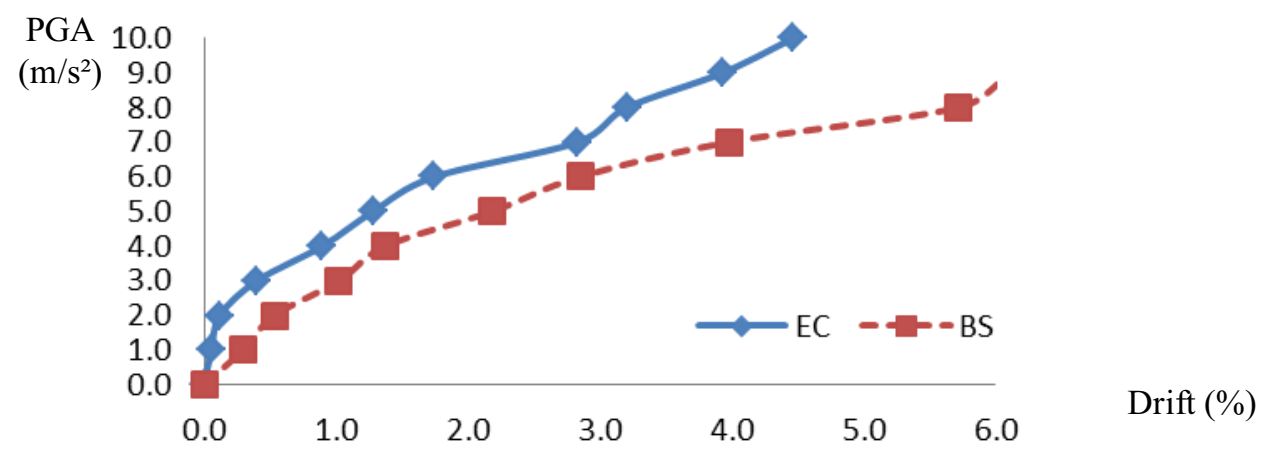

Fig. 3. IDA of the four-storey MRCF for the case of simultaneous column removal

\section{Conclusions}

This study investigated the behavior of MCRFs and compared the performances of buildings subjected to progressive collapse constructed based on BS and EC designs. Column removal simulated progressive collapse as recommended by GSA guidelines (2013). POA and IDA were performed using SAP2000. The following conclusions were drawn:

i) POA showed that the four-storey building was more vulnerable than the six-storey building. The four-storey building under the EC-based design exhibited the highest peak base force. This result was consistent with Bredean et al. [12], which indicated that low-rise reinforced-concrete buildings were more vulnerable than mid-rise buildings because of the high DCR value of the former.

ii) IDA revealed that the BS-based buildings performed better than EC-based buildings under seismic action. The four-storey MRCF was subjected to seismic loading. Two columns were removed simultaneously. The building designed based on BS recorded a PGA of $6.0 \mathrm{~m} / \mathrm{s}^{2}$ at $3 \%$ drift, whereas the building designed by the EC attained a PGA of $7.0 \mathrm{~m} / \mathrm{s}^{2}$.

This research was supported by Universiti Sains Malaysia under Short Term Grant (60313036) and Grant Contract U523. 


\section{References}

[1] O.A. Mohamed, Assessment of progressive collapse potential in corner floor panels of reinforced concrete buildings, Engineering Structure, 31, 749-757 (2009)

[2] H.R. Tavakoli and A.R. Alashti, Evaluation of progressive collapse potential of multistory moment resisting steel frame buildings under lateral loading, Scienctia Iranica, 20, 1, 77-86 (2013)

[3] M. Byfield, W. Mudalige, C. Morison and E. Stoddart, A review of progressive collapse research and regulations, Proceeding of Institute Civil Engineering, 167, 8, 447-456 (2014)

[4] British Standards Institute, Loading for buildings; Part 1: Code of practice for dead and imposed loads, British Standards Institute, London, UK, (1996)

[5] EN 1990:Eurocode, Basis of structural design, British Standards Institution, London, (2000)

[6] Strucutral Engineering Institute. Minimum design loads for buildings and other structures, Reston, Va: American Society of Civil Engineers/ Structural Engineering Institute, (2002)

[7] National Building Code of Canada, Part 4 and Commentary C, 1995 edn. National Research Council of Canada, Ottawa, Ontario (1995)

[8] U.S. General Services Administration (GSA), Alternate path analysis \& design guidelines for progressive collapse resistance, U.S. General Service Administration, (2013)

[9] Department of Defense (DOD), Interim antiterrorism/force protection construction standards- guidance on structural requirements, US Department of Defense Document, Washington, DC (2001)

[10]M. Sasani, A. Kazemi, S. Sagiroglu and S. Forest, Progressive collapse resistance of an actual 11-story structure subjected to severe initial damage, J. of Structural Engineering, 137, 9, 893-902 (2011)

[11]M. Hosseini, N. Fanaie and A.M. Yousefi, Studying the vulnerability of steel moment resistant frames subjected to progressive collapse, Indian J. of Science and Technology, 7, 3, 335-342 (2014)

[12]L. Bredean, M. Botez and A. Ioani, Progressive collapse risk and robustness of lowrise reinforced concrete buildings, Proc. of Eleventh International Conference Computer Structural Technology, Stirlingshire, 1-20 (2012) 